\title{
ПЕРСПЕКТИВЫ СТАНОВЛЕНИЯ ЕВРОПЕЙСКОЙ СИСТЕМЫ МЕСТНОГО И РЕГИОНАЛЬНОГО САМОУПРАВЛЕНИЯ
}

\begin{abstract}
Аннотация: Активизация евроинтеграчионных процессов, реформы в большинстве европейских стран в сфере местного самоуправления и регионального развития, их сотрудничество на разных уровнях обуславливают сближение территориальных общностей (обшин), их органов власти и должсностных лии, ассоииаций органов местного самоуправления и т. д. Результатом реализации программ «Европы регионов», «Европы общин» очевидно является формирование европейской системы местного и регионального самоуправления, которую можно определить как совокупность основных структурных элементов, субъектов и форм осуществления местного и регионального самоуправления, через которые европейские страны, их территориальные общины, местные и региональные органы власти, население, а также международные организации (Совет Европы, ЕС, ОБСЕ, ОЧЭС) обеспечивают реализачию права на самоуправление, соответсвующие функиии, полномочия и несут установленную ответственность.Анализируются способы ее создания, принципы, основы и субъекты, договорно-правовой и институционный механизмы обеспечения и реализаиии данной системы. Правовым оформлением ее существования, по натему мнению, является европейское муниципальное право, которое одновременно характеризуется чертами международного права, надначионального, так и внутригосударственного права.
\end{abstract}

Ключевые слова: Системы самоуправления, региональное самоуправление, принципы, территориальные обшины, ассочиачии, еврорегионы, муничипальное право, региональное развитие, трансграничное сотрудничество, хартия. Abstract: Activation of the Eurointegrational processes, reforms within most of the European countries in the area of local self-governance and regional development and their cooperation on various levels determines the coming together of territorial communities, their authorities and government officials, associations of the branches of local self-governance, etc. The result of implementing programs such as "Europe of Regions" and "Europe of Communities" evidently became the forming of the European system of local and regional self-governance, which can be defined as a combination of the main structural elements, subjects and forms of implementation of the local and regional self-governance, through which the European countries, their territorial communities, local and regional branches of authority, population, as well as international organizations (Council of Europe, EU, OSCE, BSEC) ensure the realization of right to self-governance, related functions, and carry out the set responsibilities. The article analyzes the methods of creation of such system, the principles, bases and subjects, legal-contractual and institutional mechanisms of ensuring and implementing this system. In author's opinion, the legalization of its existence lies in the European Municipal Law, which is simultaneously characterized by the features of international law, supranational, as well as internal national law.

Keywords: Systems of self-governance, Regional self-governance, Principles, Terriotorial communities, Associations, Euroregions, Municipal law, Regional development, Transboundary cooperation, Charter.

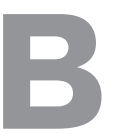

общественной жизни и политическом строе Европы на сегодня ярко выражена тенденция к интеграции в рамках ЕС и других структур, к попыткам создания европейского гражданского пространства, європейского правового пространства, європейского экономического пространства. Это существенно влияет на развитие местной и региональной демократии, функционирование местного и регионального са- моуправления, а также на определение и реализацию государственной политики на национальном, региональном и местном уровнях.

Во многих европейских странах наблюдается постоянное столкновение интересов по поводу того, в каком направлении будут развиваться евроинтеграционные процессы, базовые европейские демократические ценности и баланс власти внутри наднациональных и других общеевропейских 


\section{Право и политика $2(182) \cdot 2015$}

структур. Очевидно, что результатом реализации программ «Европы регионов», «Европы общин», Европейской политики соседства является формирование европейской системы местного и регионального самоуправления (ЕСМРC).

В этом контексте определяющую роль играет, в первую очередь, международная организация с большим опытом поддержки демократических институций в европейских странах, разработки и принятия международно-правовых стандартов защиты прав человека, местного самоуправления, регионального и пространственного развития. Безусловно, это Совет Европы - межправительственная организация, призванная обеспечить демократическую стабильность в Европе через поддержку политических, законотворческих и конституционных реформ и т. п.

Именно эта организация способствовала, по нашему убеждению, закладыванию фундамента будущей ЕСМРC. Почвой такого вывода является большое количество принятых международно-правовых актов разной юридической силы в сфере местного самоуправления, регионального/ пространственного развития, региональной автономии, трансграничного сотрудничества, верховенства права, защиты прав человека и т. д. Следует подчеркнуть весомые программы и проэкты, основанные и реализованные под эгидой Совета Европы, а также совместно при участии ее органов, представительств.

Неопровержимой является роль и значение в данном процессе других международных организаций в европейском регионе. Идет речь как об организациях универсального, так и регионального характера, что способствуют активному сотрудничеству европейских стран, внедрению правовых стандартов в упомянутых отраслях.

В современной литературе можно встретить похожие позиции европейских и отечественных авторов. Как утверждает один из постсоветских исследователей, сближение правовых систем в рамках европейского содружества свидетельствует о формировании европейской системы местного самоуправления, в которой действуют соответствующие нормативные акты. ${ }^{1}$

По нашему мнению, целесообразно вести речь о ECMPC как совокупности основных структур-

\footnotetext{
1 Чихладзе Л.Т. Местное самоуправление и местное управление зарубежных стран и государств-участников СНГ. Сравнительно-правовой анализ. - М.: Нота Бене, 2005. - С. 53.
}

ных элементов, субъектов и форм осуществления местного и регионального самоуправления, через котрые современные европейские страны, их территориальные общества и население, а также соответствующие местные и региональные органы власти обеспечивают реализацию права на самоуправление, предоставленные им функции, полномочия и несут за их невыполнение или ненадлежащее исполнение установленную ответственность. Как нам представляется это ее широкое значение.

В то же время, в узком понимании ЕСМРС составляет совокупность международно-правовых норм, принципов, стандартов и инструментов сотрудничества, которые создаются и реализуются при участии, в частности, Совета Европы, ЕС, ОБСЕ, ОЧЭС и др.

Современная ЕСМРС существует рядом с другими европейскими системами, а именно европейской системой безопасности, ${ }^{2}$ европейской экономической системой, европейской валютнофинансовой системой и рядом других. При этом можно согласиться с известным исследователем науки международного права, конституционного и муниципального права М.О.Баймуратовим, что идет речь о локальных международных системах разного характера, которые являются функциональными, рядом с универсальными международными системами. ${ }^{3}$

Приведенные европейские системы рассматриваются составляющими более широкого явления - европейского гражданского пространства. Иногда используется вместо последнего похожие, но в то же время отличны другие понятия - европейское правовое пространство, европейское административное пространство, европейское политико-правовое пространство и т. п.

Больше внимания в юридической литературе уделяется исследованию европейского правового пространства. ${ }^{4}$ Можно согласиться с такими исследователями как М. Гнатовский и ряд других относительно его определения как правовой

\footnotetext{
${ }^{2}$ Делінський О. А. Європейська система безпеки: міжнародно-правові аспекти становлення і розвитку: автореф. дис. ... канд. юрид. наук / О. А. Делінський. - Х., 2003. - С. 5-12.

${ }^{3}$ Баймуратов М. О. Локальна система захисту прав людини в Україні : сутність та становлення / М. О. Баймуратов // Юридична освіта і правова держава. Зб. наук. пр. - 1997. - С. 96-101.

${ }^{4}$ Саидов A. X. Концепция «европейского правового пространства»: проблемы и перспективы // Московский журнал международного права. - 1992. - № 3. - С. 59-72.
} 
системы в состоянии становления, составляющими которой являются юридические нормы, принципы и стандарты, разработанные в рамках региональных международных организаций (EC, CE, ОБCE), а также механизм согласования на их основе национальных правовых систем государств Европы, которая охватывает не только правовые нормы, но и правовую культуру, правовое сознание и представление о ценности права. ${ }^{5}$ Концепция “европейское правовое пространство” является результатом длительного исторического развития идей обеспечения единства государств европейского континента правовыми средствами, а ее историческим прототипом было средневековое ius commune как выработана постглоссаторами на основе римского права система норм, общих для стран континентальной Европы.

Составляющими этого понятия является региональное международное публичное право, которое определяет принципы мирного сосуществования и сотрудничества государств, а также национальные правовые системы государств Европы, предусматривающие определенную степень их сближения на основании международных документов. В целом эта среда, в которой на грани национального и международного права формируется европейское право - правовая система, общая для всех государств Европы.

Возможно, более точнее является подход, согласно которому европейское правовое пространство составляет своеобразную региональную правовую систему наднационального характера, которая объединяет национальные правовые системы и правовые системы международных организаций, принимающих участие в общеевропейском процессе (ЕС, СЕ, ОБСЕ и др.). В таком виде это понятие тем самым обеспечивает необходимые предпосылки общеевропейского правового сообщества. По нашему убеждению, европейское правовое пространство является слишком широким, в некоторой степени абстрактным понятием, что усложняет как его исследование, так и возможность точного выделения в его структуре определенных подсистем, отраслей и других составных элементов (правовых установок, процедур, механизмов).

В свою очередь, понятие европейского гражданского пространства анализируется и приме-

\footnotetext{
${ }^{5}$ Гнатовський М. М. Становлення та тенденції розвитку європейського правового простору : дис.... канд. юрид. наук / М. М. Гнатовський. - Київ, 2002.
}

нится в процессе правотворческой деятельности $\mathrm{EC}$, в первую очередь, при разработке Белой книги, Лиссабонского договора, реализации реформы европейского управления. ${ }^{6}$ Учитывая то. что эта реформа невозможна без поддержки существующих и будущих государств-членов $\mathrm{EC}$, их региональных и местных органов власти, гражданского общества, стало необходимым получить их поддержку, повысить уровень доверия к институциям ЕС и возможность ЕС влиять на глобальные события.

Европейское гражданское пространство все же кажется более приемлемой базой существования ЕСМРС, чем европейское политико-правовое пространство, поскольку данная система охватывает не только правовые инструменты, а также политические, экономические и связаны с ними другие составляющие, факторы влияния на ее формирование и функционирование.

ЕСМРС создается и функционирует не только на многосторонней основе, в рамках региональных международных организаций, интеграционных объединений. Она предусматривает возможность двустороннего уровня сотрудничества при участии соседних пограничных и других местных (региональных) органов власти разных европейских государств, их территориальных общин, неправительственных организаций и т. п.

Эта система тем эффективнее, чем больше государств входят в организации, деятельность которых направлена на ее создание, а также чем больше территориальных общин и других участников принимают участие в реализации разнообразных форм местного и регионального самоуправления.

Способами ее создания могут быть правотворческая и правоприминительная деятельность 1. региональных международных организаций, включая их совместную деятельность с международными организациями универсального характера;

2. европейских государств, направленная на сближение их правовых систем;

3. аминистративно-территориальных единиц европейских государств (автономий, регионов, областей, кантонов, муниципалитетов,

\footnotetext{
${ }^{6}$ Теорія та практика європейського врядування: навч./ Л. Л. Прокопенко, О. М. Рудік, І. Д. Шумляєва, Н. М. Рудік. - Д.: ДРІДУ НАДУ, 2009. -. 216 c.; White Paper in preparation of the associated countries of Central and Eastern Europe to integration into the internal market of the Union/ COM (95) 163.
} 


\section{Право и политика $2(182) \cdot 2015$}

районов, городов, сел и т.п.), территориальных общин иностранных государств и их объединений;

4. деятельность других субъектов в условиях евроинтеграционных процессов, региональных процессов правовой конвергенции и т. д. Сближение систем местного и регионального самоуправления европейских стран предусматривает широкомасштабный процесс сближения их правовых систем, законодательства, правовой культуры и правового сознания, а также сближение правовых систем международных организаций, принимающих участие в общеевропейском процессе (ЕС, РЕ, ОБСЕта др.).

Иногда система местного самоуправления национального уровня включает систему органов, должностных лиц и форм реализации местного и регионального самоуправления, то есть функционирует на двух уровнях:

- непосредственно местном (локальному),

- региональном (субнациональном, промежуточном).

Следовательно, можно рассматривать ЕСМРС по аналогии в двух измерениях. Это подчеркивает и тот факт, что не во всех государствах полноценно функционируют органы местного самоуправления именно на региональном уровне в соответствии с существующими международно-правовыми стандартами и потребностями населения, территориальных общин. Однако, как нам видится, это вопрос времени.

В любом случае, анализ большого количества научных исследований позволяет сделать вывод о том, что неопределенность состояния позитивного права, которое способствует его нарушением, опасность несогласованности большого количества международно-правовых норм и другие факторы указывают на определенные недостатки существующей системы международно-правового регулирования. При этом, тенденции глобализации, интернационализации права подчеркивают наиболее распространенную форму реализации интеграцию правовых систем, ${ }^{7}$ особенно ярко это проявляется на европейском региональном уровне.

Весомое значение играет главным образом относительное новая категория -юридический регионализм. Вопрос международного реги-

${ }^{7}$ Богатырёв В.В. Глобализация права : автореф. дис. ... докт. юрид. наук / В.В. Богатырёв. - Владимир: ВЮИ ФСИН России, 2012 / [Електронный ресурc]. - http://www.famous-scientists.ru/list/13144 онализма является многогранным, поскольку касается разнообразных сфер - политической, экономической, идеологической, юридической и т.п. ${ }^{8}$ Относительно юридической стороны, то центральным вопросом является содействие создания региональных институтов и усиление процесса создания региональных норм. Не означает ли это стремление обойти унверсальные мировые механизмы и замедление разработки, принятие универсальных международно-правовых норм (возможно норм глобального права)?

Хотя есть сферы отношений, которые регулируются источниками международного права (универсального характера), другие - региональными правовыми системами или исключительно на национальном уровне. Практика реализации упомянутых процессов свидетельствует об эффективности управления, функционирования региональных правовых систем, они более доступны участникам, легче управляемые и контролируемые.

Таким образом, становление ЕСМРС является закономерным следствием политической и правовой интеграции, международного регионализму. Есть основания не отрицать в известной степени самостоятельное развитие ЕСМРС, а также возможность ее последующего функционирования, равно как и соответствующих исследований структурных элементов, порядка функционирования данной системы и, в первую очередь, соответствующих методологических подходов и принципов.

Любая система местного и регионального самоуправления, независимо от того или мы ее рассматриваем в общеевропейском или внутригосударственном контексте, базируется на соответствующих объективно сформированных в обществе экономических, социальных, финансовых, правовых и других возможностях и условиях, совокупность которых составляет основы (основания) местного самоуправления. Это те объекты реальной действительности, на которых базируется деятельность органов власти, те ресурсы, что они имеют в своем распоряжении. Наиболее распространенным является выделение правовой, территориальной и материально-финансовой основ органов публичной власти.

\footnotetext{
${ }^{8}$ Нгуен Куок Динь, Патрик Дайе, Аллен Пелле. Международное публичное право. В 2-х т. Т. 1. Кн. 1: Формирование международного права. Кн. 2: Мировое сообщество / Пер. с фр. - К.: Сфера, 2000. - C.36
} 
В этом контексте правовую основу ЕСМРС составляет совокупность соответствующих правовых источников, где закреплен порядок урегулирования общественных отношений, которые возникают в процессе организации и функционирования органов публичной власти на местном и региональном уровнях, в первую очередь, самоуправляющихся органов. Таким образом, правовую основу ЕСМРС составляют

1. Международно-правовые акты универсального характера - Международная хартия об охране исторических городов (Вашингтонская хартия) 1987 г.;

2. Правовые акты европейских организаций - Европейская рамочная конвенция о трансграничном сотрудничестве между территориальными общинами и их властями 1980 г., Европейская хартия местного самоуправления 1985 г., Европейская хартия городов (II Манифест новой урбанистики) 1992 г., Хартия КМРВЕ 1994 г., Социальная Хартия городов-членов союза Балтийских городов 2001 г.; Хартия «Города Европы на пути к устойчивому развитию (Ольборгская Хартия) 1994 г.; Европейская хартия регіонального/ пространственного планирования 1983 г. (Торремолинская хартия), Хартия об участии молодежи в муниципальной и региональной жизни 1994 г. и т.д.;

3. Международные акты рекомендательного характера, а именно акты универсального и регионального уровней - Всемирная декларация местного самоуправления 1985 г., Стамбульская декларация Хабитат II по населенным пунктам 1996 г., Декларация ГА ООН о городах и других населенных пунктах в новом тысячелетии 2001 г., Европейская декларация прав городов 1992 г., принятая CLRAE $\mathrm{CE}$, Декларация относительно регионализма в Европе 1996 г., Хельсинская декларация регионального самоуправления 2002 г. и др.

Национальные нормативно-правовые акты по вопросам местного и регионального самоуправления, в частности конституции европейских государств, законы о местном самоуправлении, самоуправлении воеводств (областей, провинций, регионов), региональном развитии, децентрализации, региональном / пространственном планировании, градостроительной деятельности, охране окружающей среды, национальных меньшинствах и т. п.
Сюда следует отнести и подзаконные правовые акты: Во-первых, это уставы территориальных общин, которые в большинстве случаев утверждаются советами или другими представительскими органами местного (регионального) самоуправления. Во-вторых, это акты, принятые органами или должностными лицами местного и регионального самоуправления, в частности регламенты органов местного и регионального самоуправления, типичные правила застройки территорий, планы социально-экономического развития, решения о принятии бюджетов.

Особенную группу (подгруппу) здесь можно выделить относительно решений местных или региональных референдумов, специальных договоров нормативного характера (целевых контрактов, межотраслевых или других соглашений), заключенных специально уполномоченными субъектами.

Территориальная основа местного и регионального самоуправления предусматривает определенные пространственные и графические пределы, где территориальная община может осуществлять свою власть прямо либо опосредственно, как правило, в пределах административных границ населенных пунктов. Такой основой местного самоуправления на внутригосударственном уровне являются - село, поселок, город, добровольные объединения сел., а регионального самоуправления - район, область, район в городе или города общегосудаоственного значения. Территориальная основа ЕСМРС основывается на государственной территории, территориях государств-членов соответствующих международных организаций, АTE субнационального и других уровней.

В жизни государств, европейском гражданском пространстве данная система эффективно функционирует именно при участии регионов или других ATE такого уровня, территориальных общин городов, их объединений, реже территориальных общин или соответствующих органов власти села. Но именно сельская местность охватывает $85 \%$ территории Европы и в ней расположено жилье больше половины ее жителей, ${ }^{9}$ поэтому в Рекомендации СЕ 107(2002) «О проблемах сельской местности в Европе» предусмотрено необходимость укрепления значение сел, маленьких

\footnotetext{
${ }^{9}$ Программа ООН по населенным пунктам / [Електронний ресурс]. - Режим доступа: www.un.org/ru/ga/habitat/
} 


\section{Право и политика 2 (182) 2015}

городов как составных сельских регионов, содействия развитию жизнеспособных сельских общин и возобновлению сел.

«Регионы» во Франции, Италии, Бельгии; «земли» в Германии и Австрии; «автономные содружества (общества)» в Испании; «окружные советы» в скандинавских странах и Великобритании; «провинции»в Нидерландах, Бельгии, Италии, Испании; «области»и т. п. постепенно стали субъектами европейской региональной политики.

Поэтому Декларация относительно регионализму в Европе 1996 г., Хартия содружества о регионализации 1988 г., учредительные договоры и другие акты ЕС, а также Хартия КМРВЕ 1994 г., Хельсинская декларация регионального самоуправления 2002 г., Рекомендации КМРВЕ «О международном сотрудничестве на региональном уровне» 99(2001), «О стабильных регионах в контексте глобализации» 138(2003), проэкты Европейской Хартии региональной автономии, Хартии регионального самоуправления, Европейской Хартии региональной демократии подчеркивают роль регионов европейских государств в укреплении демократии, определяют их пространственной основой для международного сотрудничества.

Понятие «город»все более отождествляется с самоуправляющимся обществом (commune, municipium, municipio, gemeinde) как специфический автономный населенный пункт, объединяющий сообщество жителей с определенными интересами, населенным центром с организованным строительством, коммунальным обслуживанием и своей собственной администрацией [178, с. 42].

Несмотря на то, что сегодня регионы и города Европы не всегда имеют одинаковые конституционные, административные и материальные возможности для эффективного участия в межправительственном сотрудничестве, международные организации рекомендуют государствам-членам создать благоприятный климат и условия для эффективного развития их международного сотрудничества.

Важным достижением является разработка в рамках ЕС универсальной региональной статистической системы классификации территориальных единиц, что является наиболее пригодным инструментом для оценивания региональным проблем и уровня региональной экономической возможности в ЕС. Здесь они определяются в со- ответствии с Номенклатурой территориальных единиц для статистики N.U.T.S., используемой с 1988 г., измененной 2003 г. Эта пятиуровневая иерархическая система классификации базируется на принципе комплиментарности и включает три региональных уровня (NUTS 1-3), два местные (NUTS 4-5). Они отвечают численности населения в административно-территориальных единицах: NUTS I - от 3000000 до 7000 000; NUTS II - от 800000 до 3000 000; NUTS III - от 150000 до 800000 жителей. Ниже расположены “местные административные единицы” (LAU), создание которых является добровольным странами-членами ЕС, в отличие от обязательного регионального уровня для потребностей планирования и статистики, которые отвечают системе NUTS. ${ }^{10}$ Также ее значение заключается в как можно более ровной регуляции неминуемого процесса изменений административных структур стран-членов с целью минимизации их влияния на доступность, возможности сравнения региональных статистических данных.

Составляющими территориальной основы ЕСМРС можно считать также и географические части Европы: центральноевропейскую, восточноевропейскую, северноевропейскую и др.

В последнее время восточноевропейский регион характеризуется тем, что большинство его государств является членами СЕ, ОБСЕ, но не все из них являются членами ЕС. Это тормозит развитие ЕСМРС, препятствует надлежащей реализации европейских стандартов, программ и проэктов, иногда и сотрудничеству европейских стран. Черноморский регион определяют как особенное географическое пространство со значительным населением, природными ресурсами, расширяемым рынком, это важный узел, через который проходят энергетические и транспортные потоки Европы, Центральной Азии и Ближнего Востока. Сюда входят Болгария, Румыния, Украина, Россия, Турция, Албания, Сербия, Грузия, Молдова, Армения, Азербайджан, Греция. Хотя четыре последних государства не являются прибрежными, история, приближенность и их связки вынужда-

\footnotetext{
${ }^{10}$ Regulation (EC) No 1059/2003 of the European Parliament and of the Council of 26 May 2003 on the establishment of a common classification of territorial units for statistics (NUTS) //Special edition in Czech Chapter 14. Volume 01.-21.6.2003-P. 196-238. Nomenclature des unités territoriales statistiques / [Електронний ресурс]. - Режим доступа: http//ec.europa.eu/comm/eurostat
} 
ют относить к членам этого региона. ${ }^{11}$ Для этого региона характерны «замороженные» конфликты, экологические проблемы и недостаточный контроль на границах, что способствуют незаконной миграции и организованной преступности, столкновению глобальных интересов.

Материально-финансовая основа ЕСМРС предусматривают выделение двух составляющих. К материальной относят имущественные ресурсы коммунальной и др. формы собственности (в установленных правовыми актами случаях), земельные ресурсы или объекты, находящиеся в собственности субъектов ЕСМРС. Конституции к ней относят движимое и недвижимое имущество, доходы местных бюджетов, другие средства, землю, природные ресурсы, которые есть у собственности территориальных общин (ст. 142 Конституции Украины). ${ }^{12}$

Толкование статей Европейской хартии местного самоуправления 1985 г. позволяет сделать вывод о том, что местное самоуправление предусматривает возможность местных советов владеть как финансовыми ресурсами, так и материальными ценностями, эту собственность следует считать существенной и неотъемлемой составляющей местного самоуправления. ${ }^{13}$

Несмотря на отличие процедур приобретения и использования объектов коммунальной собственности в европейских странах, в некоторых из них коммунальная собственность или ее часть может материально обеспечивать или быть конфискованной и/или проданой. Органы местного самоуправления всех уровней имеют право учреждать коммерческие компании и создавать объединения с другими органами местной власти или юридическими лицами благодаря передаче им собственности, управлению определенной коммунальной собственностью. Существуют разные способы налогообложения коммунальной собственности, налог на нее является бюджетным

\footnotetext{
${ }^{11}$ Синергія Чорноморського регіону - нова пропозиція регіонального співробітництва: повідомлення Комісії для Ради та Європейського парламенту $\operatorname{COM(2007)~} 160$ / [Електронний ресурс]. - Режим доступа: http://ec.europa.eu

12 Конституція України // Відомості Верховної Ради України. 1996. - №30. - Ст.141 / [Електронний ресурс]. - Режим доступа: http://www.zakon.rada.gov.ua/

${ }^{13}$ Європейська хартія місцевого самоврядування (офіційний переклад) 1985 р. / [Електронний ресурс]. - Режим доступа: http:// www.coe.kiev.ua/
}

или внебюджетным источником органов местной (региональной) власти.

В Рекомендации «О коммунальной собственности в свете принципов Европейской хартии местного самоуправления» №132 (2003) предусмотрена необходимость гарантирования органам местной власти права владеть коммунальной собственностью в интересах местной общины. Тут идет речь о том. что государства должны обеспечить прозрачность управления и открытость по делам, связанных с коммунальной собственностью, право обращаться к судебной защите. ${ }^{14}$

Финансовая основа ЕСМРС включает доходы местных бюджетов, средства общегосударственных бюджетов, финансовые ресурсы европейских региональных организаций, местные и региональные банковские ресурсы, дотации, субвенции, трансферты и тому подобное. В соответствии с хартией 1985 г. финансовые ресурсы органов местного самоуправления должны отвечать полномочиям, которые предоставлены Конституцией или соответствующим законом. Поэтому в Рекомендации 228 (2007) закреплена необходимость определения в законодательстве принципа сопроводительного финансирования, в соответствии с которым местные органы власти в пределах национальной экономической политики имеют право на получение прогнозируемых средств, достаточных для их полномочий и ответственности. ${ }^{15}$ Местные органы власти при формировании финансовых средств свободно определяют уровень сборов, местного налогообложения согласно закону.

Следует вспомнить и о Рекомендациях «О финансовых ресурсах органов местной власти и их обязанностях: тест на субсидиарность» № 87 $(2000)$, «О финансовом и бюджетном управлении на местном и региональном уровнях» № $\operatorname{Rec}(2004) 1$, «О финансовых источниках органов местной и региональной власти» № $\operatorname{Rec}(2005) 1$ и др. Большое внимание уделяется финансовой основе при реализации локальных, в большинстве случаев региональных программ в пределах ЕС за счет общих доходов ЕС от внешнего таможен-

\footnotetext{
${ }^{14}$ Про комунальну власність у світлі принципів Європейської хартії місцевого самоврядування: Рекомендація 132(2003). / [Електронний ресурс]. - Режим доступа: http//www.coe.org/cplre/

${ }^{15}$ Recommendation 228 (2007) Draft Additional Protocol to the European Charter of Local Self-Government / [Електронний ресурс]. - Режим доступу : https://wcd.coe.int/
} 


\section{Право и политика 2 (182) 2015}

ного тарифа и других поступлений, при участии Европейского фонда регионального развития, Европейского социального фонда, Европейского фонда ориентации и гарантий для сельхозпроизводства и др.

Ограничения финансовой самостоятельности не должны ставить под угрозу принципы местного (регионального) самоуправления, должны быть пропорциональными цели, которая достигается. Другая важная проблема - финансовая помощь со стороны структурных фондов ЕС депрессивным территориям и регионам. Решающую роль в выделении субсидий и дотаций играют национальные правительства, действующи исходя чаще из собственных интересов, чем из интересов местности или региона - объекта финансирования. При этом, органы местного самоуправления оказываются отстраненными от участия в принятии важных решений. Неэффективность инструментов такой политики ведет к необходимости осуществление реформ в этой сфере, привлечения инвестиционных или других средств. За последние годы реформы в этом направлении пройшли в Португалии, Испании, Великобритании, как правило на всех территориально пространственных уровнях. Одновременно отмечается тенденция к укреплению потенциала единиц среднего звена, как правило, коммун, районов и т. п. ${ }^{16}$

Конечно, развитие общественных отношений будет вносить коррективы, что предопределяет необходимость усовершенствования основ ЕСМРС, их оптимизацию, повышение эффективности для удовлетворения потребностей местного и регионального, межрегионального значения.

В то же время любая система, включая ЕСМРС, характеризуется наличием основных принципов, исходных положений ее организации и функционирования. Первую группу принципов ЕСМРС составляют основные принципы международного права, касающиеся международно-правовых отношений универсального и регионального характера. Ко второй группе можно отнести определяющие принципы ряда международных организаций - CE, ЕС, ОБСЕ, ОЧЭС, что отображены в их учредительных документах и др. актах. Например, в ДЕС определено ключевые принципы, являющиеся основой региональной политики ЕС,

${ }^{16}$ Шишкина Н. Э. Местное управление в зарубежных странах: сущность и современные проблемы развития. - Иркутск, 1995. - C. $42-43$. имплементированные в региональные стратегии стран-участниц: - децентрализация; - субсидиарнисть; - концентрация; - программный подход; - партнерство; - комплиментарность. ${ }^{17}$

Третья группа - это непосредственные принципы ЕСМРС, а именно

- демократического управления;

- субсидиарности;

- эффективного управления и администрации;

- организационной, правовой, финансово имущественной самостоятельности местных и региональных органов власти;

- децентрализации власти;

- лояльности и соблюдение территориальной целостности;

- сплоченности и вездесущности местного и регионального самоуправления;

- сопроводительного финансирования.

Среди других принципов ЕСМРС можно выделить принципы публичной этики, солидарности, участия граждан в управлении публичными делами, отчетности, эффективности, последовательности и т. п. Отдельные акты могут устанавливать узко специальные принципы данной системы (Европейская хартия городов (Манифесте) сформулировала принципы новой урбанистики, которые должны стать основой для будущих изменений). Следует отметить и характерные принципы европейского регионализма, региональной политики, транграничного сотрудничества как составляющих ЕСМРС. При имплементация таких базовых принципов необходимым является соблюдение общегосударственных интересов и прав человека, сочетания национальных, региональных и местных интересов.

Конституирование ЕСМРС предопределяет сосуществование различных взаимодействующих субъектов (участников), выяснение их значения для современного европейского пространства. Если субъекты международного права имеют общую, отраслевую и специальную правосубъектность, то можно проанализировать статус субъектов ЕСМРС, классифицируя их таким образом

Государства, наделенные общей правосубъектностью, характеризуются способностью ipso facto (в силу факта своего существования)

\footnotetext{
17 Treaty on European Union / [Електронний ресурс]. - Режим доступу: http://www.eurotreaties.com/maastrichtext.html.
} 
выступать в качестве субъекта международноправовых отношений.

Международные межправительственные организации владеют отраслевой (реже межотраслевой) правосубъектностью, которым свойственная способность субъектов международного права выступать в качестве участников в определенной сфере международных отношений.

Территориальные (региональные) общины, международные неправительственные организации, физические и юридические лица, ассоциации и другие объединения органов местного и регионального самоуправления наделены специальной правосубъектностью, то есть способностью быть участниками определенного круга отношений в рамках отдельной отрасли или круга отношений.

Конечно, речь идет о том, когда государство в национальном законодательстве наделяет этих участников соответствующей компетенцией. При этом стоит отметить, что все же они на сегодня остаются полноценными субъектами внутригосударственного (национального) права, в междунардно-правовых отношениях они пока не достигают того уровня правосубъектности, чтобы признаваться полноправными субъектами международного права.

Так, некоторые из существующих субъектов федераций принимают участие в процессе розработки и заключения международных договоров, деятельности международных межправительственных и неправительственных организаций макро- и субрегионального характера; открытии представительств в других государствах. Субъекты федерации частично наделены признаками суверенитета, но не наделенные правом выхода из федерации - сецессии; запрещено или существенно ограниченное право осуществлять самостоятельно международную политику (кроме внешнеэкономической деятельности, как правило, с разрешения федеральных органов).

Ярким примером осуществления внешних зносин региона является Представительство региона Стокгольма в Санкт-Петербурге, которое создано в результате заключения нового Соглашения о сотрудничестве между Санкт-Петербургом и Стокгольмом 1997 г. в рамках реализации идеи Европы регионов. Представительство реализует информационную деятельность, создает возможности для сотрудничества и развития долговременных связей между Северным Западом России и регионом Стокгольм-Меларен, в частности через продвижение общих проектов. Это представительство способствует углублению контактов между органами власти, деловыми и академичними кругами регионов. Офисы Представительства региона Стокгольма находятся также в Брюсели, Варшаве и Стокгольме.

Касательно такой категории субъектов в ЕСМРС как АТЕ, то они являются субъектами правоотношений и имеют свой статус. Основой территориального образования как обособленной составной части территории государства, в которой функционируют соответствующие органы власти, есть определенная территория и население, проживающе на этой территории, территориальный коллектив (община как часть населения государства). Таким образом, можно выделить такие элементы правового статуса территориальных образований: - социальное назначение; - компетенция (функции и полномочия); - порядок формирования (способ легитимизации), изменения и ликвидация; - четко определены административно-территориальные пределы; внутренняя организация (организация власти, ее взаимоотношения с центральной властью и другими территориальными образованиями); ответственность.

Конкретное содержание этих элементов в их взаимосвязи позволяет определить место и роль каждого территориального образования в системе территориальной организации государств, в процессе их международного сотрудничества. АТЕ различают в соответствии с уровнем территориального распределения. Автономии, например, - классические «искусственные» АТЕ, в то же время как города - это самые распространенные в европейском политико-правовом пространстве «естественные» АТЕ, является своего рода генераторами социальных изменений в обществе. Это в наибольшей степени проявляется конечно на внутригосударственном уровне, однако находит свое отображение и на международном региональном уровне.

В европейских странах автономия - это важное средство и проявление децентрализации, демократизации, форма урегулирования межэтнических отношений. В Португалии автономные области - остров Мадейра и Азорские острова - территориальные юридические лица, которые имеют, кроме прочях, полномочия по образованию местных са- 


\section{Право и политика 2 (182) 2015}

моуправляющихся единиц, их опеки; повышения категории населенных пунктов; право принимать участие в переговорах о заключении международных договоров; сотрудничества с другими иностранными региональными образованиями в процессе европейского строительства. ${ }^{18}$ При вступлении Дании в ЕС, гренландцы, отказавшись на референдуме от участия в нем, создали прецедент, когда Дания стала членом ЕC, а ее автономия нет. ${ }^{19}$

Как видим, автономия пользуется самостоятельностью во многих сферах деятельности, потому стала объектом регулировании в Проэкте Европейской Хартии региональной автономии. ${ }^{20}$ Несмотря на это, на сегодня ее международная правосубъектность имеет усеченный характер, реализуется в большей степени не непосредственно, а через деятельность других субъектов, которые владеют активной правосубъектностью.

Процесс европейской интеграции постепенно превратил до недавнего времени периферийные области государств, которые были долгое время изолированными и маргинальными, в области перекрестки новой Европы. Они характеризуются особенным статусом, становятся стратегическими единицами, где местным содружествам (общинам) отведена важная роль. ${ }^{21}$ Субъектом является не собственно территория, а именно определенным образом организованы АТЕ.

ЕС предусматривает особенные образования в своих государствах-членах, с которыми находится в непосредственных отношениях, - регионы - третий уровень территориальной организации власти, что подчиняется ЕС и государствам-членам, формируя тем самым основы европейского регионализма. То есть это незаменимый элемент европейского развития и интеграции, несмотря на разные наименования, количество, происхождениея и функции. Современная региональная политика СЕ раскрыла новое виденье региона и согласно

\footnotetext{
${ }^{18}$ Конституционное право Европейского союза / [Електронний peсурс]. - Режим доступу : http://moodle.ehu.lt/course/info. php?id=1136

19 Лукашева Н. В. Правовое положение автономных образований в странах Северной Европы : дис. ... канд. юрид. наук / Н. В. Лукашева. - Екатеринб., 1998. - 185 с.

${ }^{20}$ Recommendation 34 (1997) sur le projet de Charte europeenne de l'autonomie regionale / [Електронний ресурс]. - Режим доступу: http//www.coe.org

${ }^{21}$ Альварес Бернад и де Еулат. Приграничное сотрудничество региональных и местных властей. / Курс Гаагской Академии международного права. Т. 243. - Г. - М., 1996.
}

Европейской рамочной конвенции о трансграничном сотрудничестве между территориальными общинами или властями 1980 г., дополнительных протоколов к ней, Европейской хартии местного самоуправления 1985 г., др. актов предусмотрена возможность развития пограничного сотрудничества, межрегионального и другого сотрудничества территориальных общин, их органов власти.

В конвенции в 1980 г. закреплены принципы международного сотрудничества между соседними (пограничными) регионами государств, организации и функционирования «еврорегионов» как макрорегиональных интеграционных структур международного характера с развитой общей социально-экономической инфраструктурой. ${ }^{22}$ Большинство соседних европейских государств, включая Украину, приобрели опыт в области функционирования таких объединений транснационального (трансграничного) характера.

Отметим Рекомендации КМРВЕ «О международном сотрудничестве на региональном уровне» 99(2001), «О стабильных регионах в контексте глобализации» 138(2003), где подчеркивается необходимость устранения юридических и административных препятствий, которые тормозят международное сотрудничество регионов; органы местной и региональной властей являются главными участниками концепции глобального управления, они делают свой взнос в сохранение мирового наследства окружающей среды и стабильное развитие.

В то время, когда региональные бюджеты стран-участниц РЕ в целом выросли, наблюдается разница в доступе к финансовым ресурсам на региональном уровне. В ряде стран региональный бюджет иногда меньше местного, что вынуждает совершенствовать финансово-материальное обеспечение регионов с целью надлежащей реализации ими заданий, полноценного существования с другими территориальными образованиями.

Составными элементами правового статуса города определяют: правосубъектность города, его функции и компетенцию городской власти, механизм осуществления функций города и полномочий городской власти, гарантии их реализации, юридическую ответственность городской вла-

\footnotetext{
${ }^{22}$ Європейська рамкова конвенція про транскордонне співробітництво між територіальними общинами або властями 1980 р. // Офіційний. вісник України. - 2006. - № 9. - Ст. 585.
} 
сти. ${ }^{23}$ Это связаны между собой и взаимодополняющие элементы.

Сущность такого статуса раскрывается в механизме урегулированных нормами права общественных отношений города с человеком, государством, органами государственной власти, органами и должностными лицами местного самоуправления, неправительственными организациями, с иностранными субъектами и мировым содружеством в целом. Правосубъектность города можно определить как совокупность юридических возможностей города в лице территориальной общины, органов и должностных лиц быть участником правоотношений, которые возникают в процессе выполнения городом своих функций в пределах конституции, законов и устава территориальной общины.

Воплощая процессы реализации на локальном уровне публичной власти, интересов территориальной общины в решении населением вопросов местного значения, город является не только самостоятельным субъектом правовых отношений, но и их объектом, основой реализации функций государственной власти, местного самоуправления. Следовательно, это специфический субъектобъект, особенное политико-территориальное образование, существует на основании специальных правовых актов, из которых выплывают права и обязанности города. Как субъект правоотношений город территориально и имущественно отделен, это населенный пункт, наделенный правосубъектностью особенного рода, преимущественно опосредствованной в виде суммарной правосубъектности субъектов городской власти и ведения хозяйства, юрисдикция которых распространяется на территорию города.

Современный город, выступая как «коллективно действующее лицо», в то же время является местом для инициативы и жизнедеятельности ключевого субъекта урбанистической политики национального или международного масштаба (жителя), возникновения новых форм жизнежеятельности, других социальных связей. Он напрямую сталкивается с вызовами, порожденными глобализацией.

Поэтому множественные международно-правовые акты закрепляют выработанные мировым

${ }^{23}$ Шкабаро В. М. Конституційно-правовий статус міста в Україні: автореф. дис. ... канд. юрид. наук / В.М. Шкабаро. - К., 2004. - C. 5-7. содружеством стандарты городской демократии, нормы, принципы, правовые и организационные средства, условия и требования, с помощью которых осуществляется обеспечение и защита статуса города.

Но при этом дискуссионными являются подходы относительно деликтоспособности упомянутых территориальных образований, поскольку это, в первую очередь, пространственные пределы функционирования субъектов правовых отношений и юридической ответственности. В любом случае, она проявляется не непосредственно, а в виде ответственности органов региональной/местной власти, соответствующих должностных лиц. Можно сделать вывод, что указанные субъекты являются носителями опосредствованной деликтоспособности, самостоятельно нести международно-правовую ответственность пока не могут.

Право на участие в местном самоуправлении реализуется по принадлежности к соответствующим территориальным общинам и в современных условиях растет значение этих первичных субъектов местного самоуправления. Это совокупность жителей, объединенных постоянным обитанием в пределах села, поселка, города как самостоятельных АТЕ, или добровольное объединение жителей нескольких сел, имеющих единственный административный центр. ${ }^{24}$

Следует отметить, что социально-правовая структура такого многоаспектного явления включает граждан государства и иностранцев, лиц без гражданства, которые постоянно проживают в селе, поселке, городе и пользуются по конституции такими же правами и свободами, исполняют такие же обязанности, как и граждане государства, за исключениями, установленными законами. В то же время, под общиной понимают и территориальную основу местного самоуправления, базовое звено территориального устройства государства, пределы которого являются пространственной основой деятельности субъектов местного самоуправления.

В целом это сложная форма общественной организации, совокупность местных жителей, объединенных на публичных принципах в пределах определенной территории. Они действуют на основании устава или по решению местных

\footnotetext{
${ }^{24}$ Про місцеве самоврядування в Україні: Закон України від 21 травня 1997 р. № 280/97-ВР // Відомості Верховної Ради України. - 1997. - № 24. - Ст. 170.
} 


\section{Право и политика 2 (182) 2015}

референдумов объединяются с другими общинами с целью осуществления самоуправления в пределах конституции и законов государства. Общины наделены конкретной правосубъектностью, а именно правом:

- формирования соответствующих органов путем проведения выборов, общих собраний граждан по месту жительства;

- проведения местных референдумов, инициатив, общественных слушаний, индивидуальных и коллективных обращений, общественных экспертиз и обсуждений, других незапрещенных конституцией форм местной демократии;

- управления местными бюджетами, движимым и недвижимым имуществом коммунальной собственности;

- заключать международные соглашения и т. д. Формами опосредствованной реализации общинами права на самоуправление являются органы и должностные лица местного самоуправления, соответствующие ассоциации (союзы) и т. п.

Международное сотрудничество на субнациональном уровне стало настолько необходимым, что унитарное государство Франция признало право своих территориальных содружеств (общины) коммун, департаментов и регионов заключать соглашения с зарубежными содружествами. Общий Кодекс территориальных обществ предусматривает, что “территориальные содружества (общины) и их объединения могут заключать соглашения с иностранными территориальными содружествами (общинами), их объединениями в пределах своих полномочий при соблюдении международных обязательств Франции. Тут предусмотрено создание национальной комиссии по децентрализованному сотрудничеству. ${ }^{25}$

Изучая опыт Бельгии, Испании, Италии, Германии, Франции и других европейских стран, Ж. Зиллер предлагает внедрить и полноценно использовать понятие региональная община. ${ }^{26}$ «Коллективная дееспособность» обеспечивает жителям области, других АТЕ участие в государственно-созидательном процессе через сбор

\footnotetext{
${ }^{25}$ Code general des collectivites territoriales (Общий Кодекс териториальних общин) / [Електронний ресурс]. - Режим доступу: http:// www.legifrance.gouv.fr.

26 Зіллер Ж. Політико-адміністративні системи країн ЄС. Порівнял. аналіз / Пер. $з$ фр. - К.: Основи, 1996. - С. 124-166.
}

подписей для проведения всенародного референдума, а традиционная политическая ориентация населения отдельных областей обеспечивает победу определенным политическим силам на выборах в национальныепредставительские органы. Некоторые из таких представителей, в свою очередь, будут выражать народную волю и интересы в ПАСЕ и других структурах. Также в государствах-членах ЕС этот процесс находит свое отображение в процессе проведения выборов депутатов Европейского Парламента и т. п.

Любые ограничения права на участие в местном (региональному) самоуправлении в зависимости от расы, цвета кожи, политических, религиозных и др. убеждений, пола, этнического и социального происхождения, имущественного состояния, срока проживания на соответствующей территории, по языковым или другим признакам запрещаются. Лишь в условиях военного или чрезвычайного состояния могут быть применены определенные ограничения прав территориальных общин на местное самоуправление согласно Конституции и законам страны.

Остальные субъекты местного самоуправления (формируются общиной через формы прямой и непрямой демократии, характеризуются относительно нее вторичным, производным характером. Идет речь, во-первых, об органах местного (регионального) самоуправления как структурно организованных коллективах служащих или одного служащего, наделеных властью в системе местного (регионального) самоуправления. Они являются юридическими лицами и, равно как и должностные лица местного (регионального) самоуправления, наделяются национальными законами собственными полномочиями, в пределах которых действуют самостоятельно и несут ответственность за свою деятельность в соответствии с законом.

Специфика ЕСМРС предопределяет необходимость учтения особенностей правовых систем международных межправительственных организаций регионального характера. Рядом с государствами на сегодня это те субъекты, характеризующиеся международной правосубъектностью. Именно организация и функционирование CE, ЕС и др. структур обеспечили разработку и принятие европейских правовых демократических стандартов, поддержку реформ в сфере местного и регионального развития, налаживания сотрудничества европейских стран. 
В праве Совета Европы, в отличие от права $\mathrm{EC}$, круг участников отношений является шире, а именно: государства-члены, их органы и должностные лица, неправительственные организации, индивиды (граждане государств-членов СЕ, другие лица). К примеру, активно развиваются взаимоотношения CE с международными неправительственными организациями (МНУО). Есть основания заявлять, что в ЕСМРС не исключается участие Всемирной организация «Объединенные города и органы местного самоуправления», функционирующей при участии мэров и местных органов власти. Она предоставляет местным жителям, в первую очередь, горожанам, возможность выразить свою волю и интересы на внутригосударственном и международном уровнях через демократически избранных представителей. На национальном уровне мэры и местные чиновники объединяются в ассоциации местных органов власти, которые представляют муниципалитеты, поселки и города страны. В пределах даной организации, ее отделений они активно сотрудничают, представляя интересы местного населения на международном уровне, удовлетворяя их потребности, способствуя поиску инвестиционных партнеров. ${ }^{27}$

В свою очередь, международная ассоциация неприбыльного характера - Совет европейских муниципалитетов и регионов (СЕМР) согласно Уставу 2006 г. предусматривает реализацию таких основных целей: 1) укрепление местной автономии территориальных коллективов; 2)облегчение их управления, содействие благосостоянию; 3) обеспечение участия и представительства местных, региональных территориальных сообществ в общеевропейских органах и структурах; 4) повышение роли принципов демократичекого управления и участия граждан при принятии решений; 5) стимулирование обмена опытом лучших практик между членами организации. ${ }^{28}$

СЕМР включает руководящие органы, Национальные секции и ассоциации, призванные обеспечивать должное ее функционирование. Среди ассоциаций органов местного само-

\footnotetext{
${ }^{27}$ Офіційний сайт Світової організації «Об’єднані міста та органи місцевого самоврядування» / [Електронний ресурс]. - Режим доступа: http://www.cities-localgovernments.org/index.asp

${ }^{28}$ Офіційний сайт Ради Європейських Муніципалітетів та Регіонів (CEMR) / [Електронний ресурc]. - Режим доступа: http://www. ccre.org
}

управления, их объединений можно выделить: Ассоциацию городов Албании, Ассоциацию городов и муниципалитетов Бельгии, Союз муниципалитетов Кипра, Союз городов и муниципалитетов Чешской Республики, Ассоциацию городов Эстонии, Ассоциацию финских местных и региональных властей, Секцию СЕМР во Франции, Ассоциацию городов Германии, Союз муниципалитетов и общин Греции, Ассоциацию местных властей Исландии, Союз муниципалитетов Израиля, Итальянскую секцию СЕМР, Латвийскую ассоциацию местных и региональных властей , Ассоциация местных властей Литвы, Ассоциацию муниципалитетов Нидерландов, Ассоциацию городов Польши, Испанскую федерацию муниципалитетов и провинций, Шведскую ассоциацию местных и региональных властей, Швейцарскую секцию СЕМР, Союз муниципалитетов Турции, Ассоциацию местного самоуправления Великобритании, Федерацию канадских муниципалитетов, Всеукраинскую ассоциацию сельских и поселковых советов, Всеукраинскую ассоциацию областных и районных советов, Ассоциацию городов Украины. Последние со статусом всеукраинских негосударственных организаций. доказали свою возможность защищать интересы местного самоуправления на национальном и европейском уровнях.

В целом правосубъектность неправительственных организаций имеет производный, функциональный и относительный характер касательно основных субъектов международного права.

В перспективе развитие международных политических, экономических, культурных и других отношений невозможно без территориальных общин и других социальных общностей, физических и юридических лиц, еврорегиональных объединений, ассоциаций органов местного самоуправления. Без сомнения, эти субъекты должны иметь определенный правовой статус, но необходимо, в первую очередь, проводить соответствующие теоретические, сравнительные и прикладные исследования, анализ национальных и международно-правовых актов в этой области, соответствующей практики.

Эффективное функционирование ЕСМРС, по нашему убеждению, способствует выделению самостоятельной отрасли - европейского муниципального права. Дана отрасль именно позволяет рассматривать ее составным элементом европей- 
DOI: $10.7256 / 1811-9018.2015 .2 .8854$

При цитировании этой статьи сноска на dоі обязательна

\section{Право и политика 2 (182) • 2015}

ского права (в широком смысле) или в более узком контексте - в пределах системы права ЕС, права Совета Европы и т. п.

В любои случае, наблюдается обратной связь, взаимовлияние ЕСМРС, систем местного (регионального) самоуправления европейских стран, как и их правовых, политических, экономических и др. систем. Надеемся, что результатом таких процессов станет улучшение качества жизни местного населения, экономическое благосостояние европейских стран, повышение правового сознания и культуры.

\section{Библиография:}

1. Альварес Бернад и де Еулат. Приграничное сотрудничество региональных и местных властей. / Курс Гаагской Академии международного права. Т. 243. - Г. - М., 1996.

2. Баймуратов М. О. Локальна система захисту прав людини в Україні : сутність та становлення / М. О. Баймуратов // Юридична освіта і правова держава. 3б. наук. пр. - 1997. - С. 96-101.

3. Богатырёв В.В. Глобализация права : автореф. дис. ... докт. юрид. наук / В.В. Богатырёв. - Владимир, 2012 / [Електронный pecypc]. - http://www.famous-scientists.ru/list/13144

4. Гнатовський М. М. Становлення та тенденції розвитку європейського правового простору : дис. .... канд. юрид. наук / М. М. Гнатовський. - Київ, 2002.

5. Делінський О. А. Європейська система безпеки: міжнародно-правові аспекти становлення і розвитку: автореф. дис. ... канд. юрид. наук / О. А. Делінський. - Х., 2003. - 21 с.

6. Про місцеве самоврядування в Україні: Закон України від 21 травня 1997 р. № 280/97-ВР // Відомості Верховної Ради України. - 1997. - № 24. - Ст. 170.

7. Свропейська рамкова конвенція про транскордонне співробітництво між територіальними общинами або властями 1980 р. // Офіційний вісник України. - 2006. - № 9. - Ст. 585.

8. Свропейська хартія місцевого самоврядування (офіційний переклад) 1985 р. / [Електронний ресурс]. - Режим доступу: http://www.coe.kiev.ua/

9. Зіллер Ж. Політико-адміністративні системи країн СС. Порівнял. аналіз / Пер. з фр. - К.: Основи, 1996. - С. $124-166$.

10. Конституционное право Европейского союза / [Електронний ресурс]. - Режим доступу : http://moodle.ehu.lt/course/info. php?id=1136

11. Конституція України // Відомості Верховної Ради України. - 1996. - №30. - Ст.141 / [Електронний ресурс]. - Режим доступу: http://www.zakon.rada.gov.ua/

12. Лукашева Н. В. Правовое положение автономных образований в странах Северной Европы : дис. ... канд. юрид. наук / Н. В. Лукашева. - Екатеринб., 1998. - 185 с.

13. Нгуен Куок Динь, Патрик Дайе, Аллен Пелле. Международное публичное право. В 2-х т. Т. 1. Кн. 1: Формирование международного права. Кн. 2: Мировое сообщество / Пер. с фр. - К.: Сфера, 2000. - 440 с.

14. Офіційний сайт Ради Свропейських Муніципалітетів та Регіонів (CEMR) / [Електронний ресурс]. - Режим доступу: http://www.ccre.org

15. Офіційний сайт Світової організації «Об’єднані міста та органи місцевого самоврядування» / [Електронний ресурс]. Режим доступу: http://www.cities-localgovernments.org/index.asp

16. Про комунальну власність у світлі принципів Свропейської хартії місцевого самоврядування: Рекомендація 132(2003). / [Електронний ресурc]. - Режим доступу: http//www.coe.org/cplre/

17. Программа ООН по населенным пунктам / [Електронний ресурс]. - Режим доступа: www.un.org/ru/ga/habitat/

18. Саидов А. Х. Концепция «европейского правового пространства»: проблемы и перспективы // Московский журнал международного права. - 1992. - № 3. - С. 59-72.

19. Синергія Чорноморського регіону - нова пропозиція регіонального співробітництва: повідомлення Комісії для Ради та Європейського парламенту СОМ(2007) 160 / [Електронний ресурс]. - Режим доступа: http://ec.europa.eu

20. Теорія та практика європейського врядування: навч./ Л. Л. Прокопенко, О. М. Рудік, І. Д. Шумляєва, Н. М. Рудік. - Д.: ДРІДУ НАДУ, 2009. - 216 с.

21. Чихладзе Л.Т. Местное самоуправление и местное управление зарубежных стран и государств-участников СНГ. Сравнительно-правовой анализ. - М.: Нота Бене, 2005. - С. 53.

22. Шишкина Н. Э. Местное управление в зарубежных странах: сущность и современные проблемы развития. - Иркутск, 1995. - C. 42-43.

23. Шкабаро В. М. Конституційно-правовий статус міста в Україні: автореф. дис. ... канд. юрид. наук / В.М. Шкабаро ; Інст. законод. Верховної Ради України. - К., 2004. - 21 с.

24. Code general des collectivites territoriales (Общий Кодекс териториальних общин) / [Електронний ресурс]. - Режим доступу: http://www.legifrance.gouv.fr.

25. Nomenclature des unités territoriales statistiques / [Електронний ресурс]. - Режим доступу: http//ec.europa.eu/comm/eurostat

26. Recommendation 34 (1997) sur le projet de Charte europeenne de l'autonomie regionale / [Електронний ресурс]. - Режим доступу: http//www.coe.org 
DOI: $10.7256 / 1811-9018.2015 .2 .8854$

При цитировании этой статьи сноска на доі обязательна

Интеграционное право и наднациональные организации

27. Recommendation 228 (2007) Draft Additional Protocol to the European Charter of Local Self-Government / [Електронний pecypc]. - Режим доступу : https://wcd.coe.int/

28. Regulation (EC) No 1059/2003 of the European Parliament and of the Council of 26 May 2003 on the establishment of a common classification of territorial units for statistics (NUTS) //Special edition in Czech Chapter 14. Volume 01. - 21.6.2003-P. 196 - 238.

29. Treaty on European Union / [Електронний ресурс]. - Режим доступу: http://www.eurotreaties.com/maastrichtext.html.

30. White Paper in preparation of the associated countries of Central and Eastern Europe to integration into the internal market of the Union/ COM (95) 163.

\section{References (transliterated):}

1. Al'vares Bernad i de Eulat. Prigranichnoe sotrudnichestvo regional'nykh i mestnykh vlastei. / Kurs Gaagskoi Akademii mezhdunarodnogo prava. T. 243. - G. - M., 1996.

2. Baimuratov M. O. Lokal'na sistema zakhistu prav lyudini v Ukraïni : sutnist' ta stanovlennya / M. O. Baimuratov // Yuridichna osvita i pravova derzhava. Zb. nauk. pr. - 1997. - S. 96-101.

3. Bogatyrev V.V. Globalizatsiya prava : avtoref. dis. ... dokt. yurid. nauk / V.V. Bogatyrev. - Vladimir, 2012 / [Elektronnyi resurs]. - http://www.famous-scientists.ru/list/13144

4. Gnatovs'kii M. M. Stanovlennya ta tendentsiï rozvitku €vropeis'kogo pravovogo prostoru : dis. ... kand. yurid. nauk / M. M. Gnatovs'kii. - Kiïv, 2002.

5. Delins'kii O. A. Evropeis'ka sistema bezpeki: mizhnarodno-pravovi aspekti stanovlennya i rozvitku: avtoref. dis. ... kand. yurid. nauk / O. A. Delins'kii. - Kh., 2003. - 21 s.

6. Ziller Zh. Politiko-administrativni sistemi kraïn CS. Porivnyal. analiz / Per. z fr. - K.: Osnovi, 1996. - S. 124-166.

7. Lukasheva N. V. Pravovoe polozhenie avtonomnykh obrazovanii v stranakh Severnoi Evropy : dis. ... kand. yurid. nauk / N. V. Lukasheva. - Ekaterinb., 1998. - 185 c.

8. Saidov A. Kh. Kontseptsiya «evropeiskogo pravovogo prostranstva»: problemy i perspektivy // Moskovskii zhurnal mezhdunarodnogo prava. - 1992. - № 3. - S. 59-72.

9. Chikhladze L.T. Mestnoe samoupravlenie i mestnoe upravlenie zarubezhnykh stran i gosudarstv-uchastnikov SNG. Sravnitel'nopravovoi analiz. - M.: Nota Bene, 2005. - S. 53.

10. Shishkina N. E. Mestnoe upravlenie v zarubezhnykh stranakh: sushchnost' i sovremennye problemy razvitiya. - Irkutsk, 1995. - S. 42-43.

11. Shkabaro V. M. Konstitutsiino-pravovii status mista v Ukraïni: avtoref. dis. ... kand. yurid. nauk/V.M. Shkabaro ; Inst. zakonod. Verkhovnoï Radi Ukraïni. - K., 2004. - 21 s. 